\title{
ANALISIS ESTETIKA VISUAL SENI LUKIS KARYA PESERTA DIDIK KELAS III SEKOLAH DASAR
}

\author{
Probosiwi, Wahyu Wulan Ardiyanti \\ Program Studi Pendidikan Guru Sekolah Dasar, Universitas Ahmad Dahlan, Yogyakarta 55164 \\ E-mail: probosiwi@pgsd.uad.ac.id
}

\begin{abstract}
The purpose of this paper is to describe the visual aesthetics of the thirdgrade students' painting based on lines, colors, shapes, and gradations, as well as to explain the type of painting. The method used is a qualitative type with a descriptive approach. Data collection techniques were carried out by means of observation, interviews, and document review. The results showed that based on the elements of fine art, the work of students had their beauty based on the perspective of each person who saw it, and there were various types of paintings by students. Still, the types of paintings that often appeared in the lower classes were naturalistic and transparency types. by following under the characteristics of lower-class students.
\end{abstract}

Keywords: Painting, Visual Aesthetics, Children Painting Type.

\begin{abstract}
Abstrak
Tujuan penulisan ini adalah untuk mendeskripsikan estetika visual karya seni lukis peserta didik kelas III berdasarkan garis, warna, bentuk, dan gradasi serta menjelaskan tipe lukisan. Metode yang digunakan menggunakan jenis kualitatif dengan pendekatan deskriptif. Teknik pengumpulan data dilakukan dengan cara observasi, wawancara, dan telaah dokumen. Hasil penelitian menunjukkan berdasarkan unsur-unsur seni rupa, karya peserta didik memiliki keindahannya masing-masing berdasarkan sudut pandang setiap orang yang melihatnya, serta terdapat tipe lukisan peserta didik yang beragam, namun tipe lukisan yang sering muncul di kelas bawah adalah tipe naturalistik dan tipe transparansi yang sesuai dengan karakteristik peserta didik kelas bawah.
\end{abstract}

\section{Kata Kunci: Seni Lukis, Estetika, Tipe Lukisan Anak.}

Estetika adalah ilmu tentang keindahan yang dipelajari dari berupa karya seni sebuah objek, proses kreatif, dan perencana sebagai subjek. Nilai keindahan (estetika), bukan hanya dimiliki oleh kesenian saja, namun nilai estetik juga memiliki pemaknaan menyeluruh terhadap kemampuan kreatif manusia (Putra \& Yasa, 2020).

Estetika yang dibangun merupakan istilah kiasan; sebagai selasar seni adalah keindahan sebagai hasil objektivikasi dilihat dari pandangan epistemologi. Pandangan seseorang terhadap estetika sebagai objek penciptaan karya seni dan pandangan ontologi, yaitu sebagai ruh karya sebuah seni karena keindahan suatu karya mampu diterjemahkan dan dikeluarkan melalui sumber khayalan seseorang. Estetika yang dibangun dijadikan pendekatan pembelajaran seni di sekolah umum (non-kejuruan), yaitu sebagai tujuan akhir pembelajaran seni. Seni menjadi metode pemerolehan estetika sebuah karya seni dapat diuraikan menjadi 5 hal, yaitu: (1) keindahan alam yaitu keindahan yang absolute pemberian dari sang pencipta dunia; (2) keindahan inderawi dan sensual 
yaitu yang ditangkap oleh panca indera manusia yang secara spontan berkaitan dengan kesukaan dan dikembangkan melalui kesenangan (hedonity) seperti kesukaan terhadap kecantikan susunan bunga-bunga yang berwarna; (3) keindahan (aqliyah) merupakan pemahaman indah setelah mempertimbangkan asas keberadaannya; (4) keindahan ruhaniyah (irfani) berkaitan dengan akhlak dan adanya pengetahuan tentang hakikat segala sesuatu pada diri seseorang atau karya seni, sastra, dan keilmuan; (5) keindahan Ilahiyah atau transedental (Sunarto, 2017).

Menurut Islamuddin (2012: 40-41) ada beberapa sifat khas anak-anak pada masamasa kelas rendah yakni adanya korelasi positif yang tinggi antara keadaan kesehatan pertumbuhan jasmani dengan prestasi sekolah, sikap yang cenderung untuk mematuhi peraturan-peraturan permainan yang tradisional, kecenderungan memuji sendiri, suka membandingkan dirinya dengan anak lain, jika tidak dapat menyelesaikan suatu soal maka soal itu dianggap tidak penting. Pada masa ini (umur 6-8 tahun), anak menghendaki nilai (angka rapor) yang baik, tanpa mengingat apakah prestasinya memang pantas diberi nilai baik atau tidak, sehingga sangat penting anak-anak kelas bawah untuk dikenalkan terhadap seni. Hal ini dikarenakan seni dapat menumbuhkan kreativitas yang dimiliki anak-anak dalam bentuk mengekspresikan diri dalam segi positif. Menurut Pamadhi (2012: 23), pendidikan seni merupakan pendidikan yang bersifat total kejiwaan. Pendidikan seni mengandung pelatihan berbudaya, seperti halnya pemahaman terhadap tindakan atas perilaku dan dampaknya, pengembangan rasa, serta diterjemahkannya ke dalam kognisi dan memotivasi keterampilan motorik halus. Pendidikan seni sangat diperlukan dalam dunia pendidikan agar membentuk peserta didik untuk bisa mengenal tentang keindahan sebuah karya seni yang diciptakan oleh dirinya sendiri atau orang lain. Salah satu kegiatan mengenal keindahan yaitu dengan memperkenalkan peserta didik terhadap pendidikan seni lukis.
Seni dalam ranah pendidikan menjadi salah satu fokus utama dan selalu dikembangkan dalam sebuah lembaga pendidikan salah satunya adalah seni (Siswantari \& Setyaningrum, 2019). Menurut Sumanto (2011: 16), seni lukis jenis karya seni rupa dwimatra yang keberadaannya dikatakan berumur paling tua. Sedangkan menurut Kartika (2011: 33) Seni lukis dikatakan sebagai suatu ungkapan pengalaman estetis seseorang yang dituangkan dalam bidang dua dimensi (dwimatra), dengan menggunakan medium rupa, yaitu garis, warna, tekstur, shape, dan sebagainya. Seni lukis dapat dikatakan sebagai salah satu cabang seni rupa dua dimensi yang menghasilkan sebuah karya murni secara bebas sesuai gaya setiap pribadi seseorang.

Oleh karena itu, dalam kegiatan melukis sangat mengutamakan komposisi warna dengan teknik yang berbeda-beda. Di dalam seni rupa, seni gambar, dan seni lukis memiliki perbedaan. Seni gambar merupakan proses membuat gambar yang dilakukan dengan cara menggoreskan benda tajam (seperti pensil atau pena) pada bidang datar. Hasil dari proses ini berupa tata susunan garis. Sedangkan menurut Sumanto (2011: 20), melukis adalah proses membuat gambar dengan cara menggoreskan atau melumurkan bahan warna seperti cat pada bidang datar. Namun, saat ini proses pembuatan gambar dan lukisan hampir dikatakan sama hanya saja tujuan dan hasilnya berbeda.

Seni sudah masuk ke semua kalangan masyarakat termasuk anak sekolah dasar. Di dalam pembelajaran seni tidak hanya membangun kreativitas, namun juga membangun jiwa peserta didik. Tujuan seni lukis dalam perkembangan peserta didik sekolah dasar sangatlah penting. Menurut Rustandi (2009: 1) ada empat tujuan seni lukis yaitu: a) melatih imajinasi anak; b) sebagai media pengembangan bakat; c) sebagai media bermain; d) sebagai media kemampuan berpikir. Oleh karena itu, penting bagi peserta didik sekolah dasar belajar seni lukis agar mampu mengembangkan kemampuan yang ada pada dirinya. 
Kegiatan melukis pada peserta didik dituntut untuk dapat mengembangkan imajinasi dalam karyanya agar mampu mendeskripsikan arti dari lukisannya tersebut. Hal ini bertujuan agar peserta didik dapat mengembangkan pola berpikirnya dan tidak sedikit anak yang memiliki bakat melukis. Bagi peserta didik yang memiliki bakat di bidang seni Lukis pada khsusunya dapat berkembang. Ketika seorang guru melakukan pembelajaran seni lukis dengan berbagai media, metode dan model pembelajaran yang beragam, membuat peserta didik tidak merasa jenuh, sehingga melukis bisa menjadi sarana mereka bermain bersama teman-temannya.

Teknik yang dapat digunakan dalam melukis ada bermacama-macam. Menurut Nelson (2016: 56-57) ada empat teknik dalam melukis yaitu.

a. Teknik Kering, adalah cara melukis dengan bahan yang tidak memakai bahan pencampuran air atau jenis minyak tertentu untuk melarutkannya, misalnya pastel, pensil, arang, dan konte.

b. Teknik Basah, merupakan suatu cara melukis dengan menggunakan bahanbahan yang membutuhkan pelarut seperti air atau jenis minyak tertentu. Beberapa teknik basah antara lain teknik transparan, teknk opaque, teknik relief, teknik infasto, dan teknik alaprima.

c. Teknik Batik, adalah cara melukis melalui proses menutup dengan lilin atau malam dan mencelup kecairan bahan warna. Untuk mencapai hasil yang diharapkan, keterampilan teknik yang tinggi perlu dikuasai karena sifatnya yang kompleks.

d. Teknik Campur, merupakan teknik yang unik karena dapat menggunakan lebih dari satu teknik dan media, misalnya cat air dan pastel, cat minyak dan cat akrilik, serta ditambah teknik tempelan dan sebagainya. Eksperimen sesuai dengan percobaan yang berulang-ulang dengan berbagai macam bahan melukis, maka penemuan baru terbuka di hadapannya.

Dari beberapa teknik di atas, pembelajaran seni lukis yang dilaksanakan di sekolah dasar saat ini paling banyak adalah menggunakan teknik kering terutama di kelas bawah.
Pembuatannya yang sederhana memudahkan peserta didik dalam membuat karya seni lukis saat pembelajaran berlangsung karena alat dan bahan yang digunakan mudah namun tidak menutup kemungkinan teknik lain juga digunakan dalam pembelajaran kelas bawah.

Estetika yang diciptakan dalam sebuah karya menjadikan setiap produk seni lukis memiliki ciri khasnya masing-masing. Untuk membuat lukisan agar memiliki nilai estetis, maka dibutuhkan empat unsur seni rupa, menurut Kartika (2017: 38-55) unsur yang ada dalam seni rupa yakni.

a. Garis, atau disebut juga dengan goresan adalah dua titik yang dihubungkan satu sama lain, namun garis bukan hanya sebagai pembatas saja melainkan mampu menjadi simbol emosi yang diungkapkan oleh seniman. Setiap goresan seniman memiliki karakternya masing-masing dalam setiap garis yang mereka ciptakan.

b. Warna, di dalam seni rupa murni (fine art) maupun seni rupa terapan (applied art) warna adalah unsur yang paling penting dalam setiap karya karena sebagai simbol ekspresi yang diciptakan oleh seniman.

c. Bentuk dan ruang, adalah sebuah bidang yang dibatasi oleh warna yang berbeda, bentuk merupakan perwujudan simbol seniman dalam melukiskan hasil objek yang telah dibuat.

d. Gradasi, yaitu paduan dari interval kecil ke interval yang besar, yang dilakukan secara selaras atau bertahap.

Penilaian hasil karya seni lukis sangat memperhatikan unsur dan aspek-aspek dalam seni rupa, karena di dalamnya dapat menentukan estetika atau keindahan dalam sebuah karya, serta pemahaman bagaimana seni lukis memiliki cerita atau memiliki makna walaupun anak usia sekolah dasar yang menciptakan karya tersebut.

Setiap peserta didik di dalam satu kelas pasti memiliki ciri khas dalam hasil lukisannya, sehingga setiap lukisannya dapat dikategorikan dalam tipe-tipe tertentu. Beberapa tipe lukisan anak menurut Pamadhi, S. Sukardi, dan Muis (2010: 43-46) yakni. 
1. Tipe Haptic: tipe dalam mengekspresikan perasaannya dibandingkan kejelian membuat bentuk-bentuknya.

2. Tipe Naturalistik: bisa dikatakan sama dengan realistik, karena dalam pemilihan warna sesuai dengan keadaan yang sesungguhnya.

3. Melukis cerita kepahlawanan: sebagian anak ada yang memiliki kreativitas khusus, misalnya dalam mengekspresikan karya setelah memiliki idola yang disukai.

4. Bertumpu pada garis dasar: beberapa anak memiliki cara pandang yang spasial, dapat diartikan sebuah objek dilihat hanya dari satu sisi saja.

5. Transparansi: tidak semua anak memiliki kekhasan dalam melukis, namun ada sebagian anak memilikinya salah satu ciri khasnya adalah gambar tembus pandang atau dapat dikatakan transparansi.

Dari ke lima tipe lukisan di atas, hasil lukisan peserta didik dapat dikategorikan dalam beberapa tipe lukisan agar dapat di bedakan antara lukisan satu dengan lainnya. Karena, setiap lukisan pasti memiliki ciri khasnya masing-masing dalam pembuatannya dan juga hasil produk karyanya, walaupun ditentukan dengan tema sekalipun.

\section{METODE}

Jenis penelitian yang digunakan adalah kualitatif dengan metode deskriptif yang mengacu pada hasil karya peserta didik. Menurut Moleong (2016: 11), deskriptif merupakan data yang dikumpulkan adalah berupa kata-kata, gambar, dan bukan angkaangka. Waktu penelitian pada bulan September-Oktober Semester Ganjil Tahun Ajaran 2020/ 2021. Tempat penelitian ini dilaksanakan di kelas IIIA SD Muhammadiyah Condongcatur yang melibatkan guru serta peserta didik.

Teknik pengumpulan data dilakukan dengan cara observasi, wawancara, dan dokumentasi. Menurut Moleong (2016: 176), observasi dapat diklasifikasikan atas pengamatan melalui cara berperanserta dan yang tidak berperanserta. Sehingga, pengambilan data menggunakan observasi, wawancara, dan dokumentasi dilakukan dengan peserta didik dan guru. Hasil observasi didapatkan dari produk karya lukisan peserta didik yang dikembangkan berdasarkan hasil wawancara beserta dokumentasi.

\section{HASIL DAN PEMBAHASAN}

\section{Unsur Seni Rupa terhadap} Pembelajaran Seni Lukis

Unsur seni rupa digunakan dalam proses pembuatan karya lukis, karena dengan adanya hal ini sebuah karya akan terlihat estetika secara visual. Unsur seni rupa dua dimensional yaitu garis, warna, bentuk, ruang, dan gradasi yang dapat dilahirkan melalui berbagai teknik yakni teknik goresan atau pulasan. Peserta didik kelas IIIA SD Muhammadiyah Condongcatur membuat sebuah produk karya seni lukis dengan menggunakan unsur-unsur seni rupa sesuai di bawah ini.

\section{a. Garis}

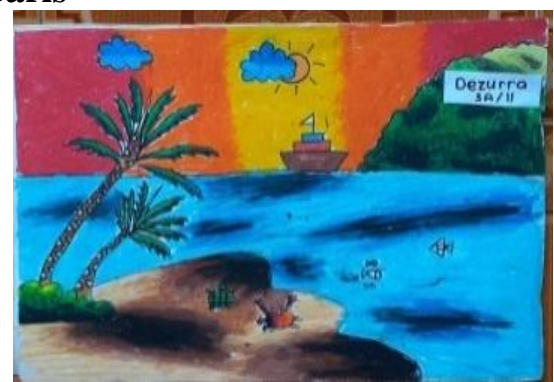

Gambar 1. Produk Lukisan (Ardiyanti: 2020)

Menurut Kartika (2017: 38) seni rupa seringkali dihadirkan garis bukan saja hanya sebagai garis, tetapi kadang sebagai simbol emosi yang diungkapkan lewat garis, atau lebih tepat disebut goresan. Dalam garis terdapat 6 macam garis yaitu garis lurus, garis lengkung, garis putus-putus, garis gelombang garis zigzag, dan garis gabungan. Dan berdasarkan hasil observasi dan dokumentasi, peserta didik di kelas IIIA rata-rata hanya menggunakan 3-5 macam garis saja, namun antara satu peserta didik dengan peserta didik lain berbeda. Penggunaan garis terbanyak dimulai dari garis lengkung, garis gabungan, garis zigzag, garis lurus, garis gelombang dan paling sedikit menggunakan garis putus- 
putus, namun walaupun demikian hasil karya lukis yang dihasilkan bagus dan memiliki estetikanya masing-masing.

\section{b. Warna}

Warna digunakan sebagai representasi alam, warna sebagai lambang/ simbol, dan warna sebagai simbol ekspresi yang digunakan oleh seniman (Kartika 2017: 38). Dalam pewarnaan terdapat berbagai macam teknik, namun di kelas IIIA hanya menggunakan teknik kering saja.

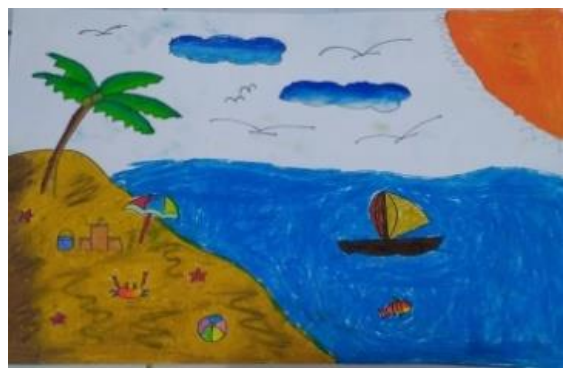

Gambar 2. Produk Lukisan Teknik Kering (Ardiyanti: 2020)

Teknik pewarnaan yang digunakan peserta didik kelas IIIA masih kurang beragam dan belum rapi, peserta didik belum berani mengekspresikan hasil karyanya, sehingga hasil warna yang dituangkan misalnya saat mewarnai awan hanya biru dan orange untuk menggambarkan waktu siang hari atau sore hari.

\section{c. Bentuk dan Ruang}

Bentuk adalah gabungan atau kumpulan dari garis sehingga membentuk satuan, atau bentukan sengaja membuat objek yang mempunyai volume (Pamadhi, S. Sukardi, dan Muis, 2010: 11-15). Dalam bentuk dan ruang pada seni lukis terdapat dua macam bentuk yakni bentuk geometris dan informal. Di kelas IIIA pembuatan bentuk dan ruang rata-rata secara informal hal tersebut sesuai dengan hasil produk peserta didik seperti milik AFN yang membuat karyanya langsung menggoreskan tanpa menggunakan bantuan penggaris atau semacamnya, sehingga bentuk yang dihasilkan banyak yang tidak simetris seperti ikan, uburubur, kepiting da lain lain.

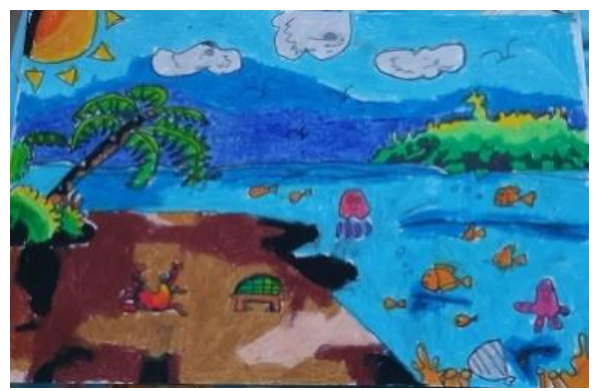

Gambar 3. Hasil karya peserta didik (sumber: Ardiyanti, 2020)

\section{d. Gradasi}

Menurut Andrisa (2007: 28), warna gradasi merupakan warna yang terdiri dari dua atau lebih yang digunakan dalam sebuah karya yang membentuk warna gabungan. Namun, penggunaan gradasi pada karya peserta didik kelas bawah masih dikategorikan sulit, hal ini dibuktikan dari produk lukisan kelas IIIA yang rata-rata belum menggunakan warna gradasi. Dari 21 peserta didik hanya 7 anak saja yang sudah membuat gradasi dalam lukisannya, karena menggabungkan warna yang sesuai satu sama lain masih sulit bagi peserta didik kelas bawah, sehingga banyak peserta didik yang memilih tidak membuat gradasi.

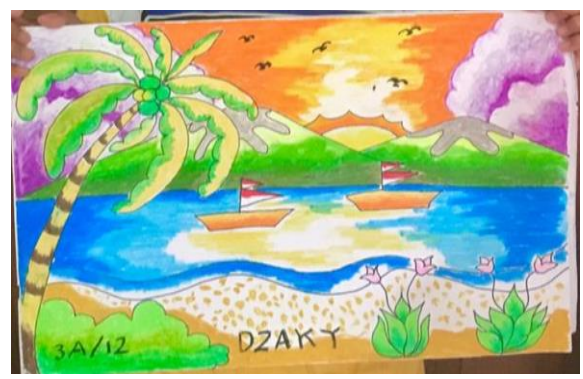

Gambar 4. Produk lukisan teknik kering (Ardiyanti: 2020) 


\section{Produk Karya Seni Lukis Berdasarkan Kategori Tipe Lukisan Peserta Didik}

Produk karya lukisan peserta didik tidak hanya memiliki satu tipe saja walaupun satu tema. Hal ini terbukti dari hasil karya peserta didik kelas IIIA SD Muhammadiyah Condongcatur yang memilki tipe lebih dari satu dalam satu karyanya. Berikut ini salah satu contoh lukisan yang memiliki tipe lukisan bertumpu pada garis dasar, naturalistik, dan transparansi.

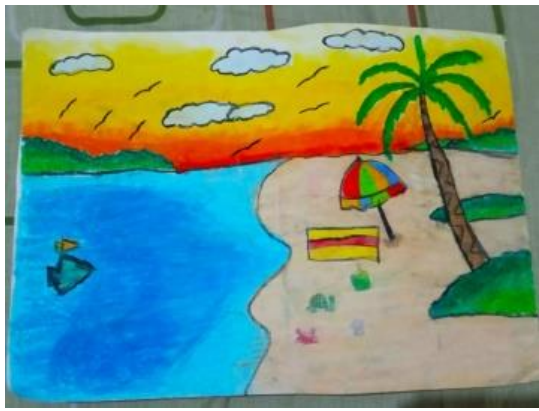

Gambar 5. Produk tipe lukisan

(Ardiyanti: 2020)

Berdasarkan hasil produk karya seni lukis peserta didik kelas IIIA memiliki tipe yang berbeda walaupun dalam satu tema yaitu "melukis pantai". Tipe yang paling banyak adalah tipe transparansi dan tipe naturalistik, hampir semua karya peserta didik masuk dalam kedua tipe tersebut. Menurut Pamadhi, S. Sukardi, dan Muis (2010: 44-46) tipe naturalistik adalah tipe lukisan yang memiiki hasil sesuai dengan realitanya, seperti misalnya gunung berwarna biru dan lain sebagainya, sedangkan tipe transparansi adalah lukisan yang memiliki ciri khas dalam hasil karyanya seperti pada gambar 6. guru membuat contoh lukisan tema pantai, namun tidak semua peserta didik mengikuti contoh yang guru buat.

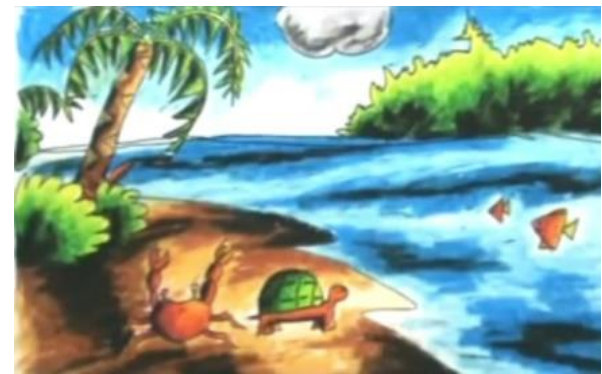

Gambar 6. Produk lukisan Bapak Hery (Sumber: Youtube SD Muhammadiyah Condongcatur, 2020)

\section{SIMPULAN DAN SARAN}

\section{Simpulan}

Berdasarkan hasil penelitian dan pembahasan, maka penelitian ini dapat disimpulkan sebagai berikut.

1. Unsur-unsur dalam seni rupa sangat mempengaruhi hasil karya seni lukis pada peserta didik kelas IIIA SD Muhammadiyah Condongcatur. Hal itu karena terdapat unsur seni antara lain garis, warna, bentuk dan ruang, serta gradasi. Dari hasil produk lukisan, unsur seni rupa yang ditonjolkan sudah masuk dalam kategori bagus. Unsur garis yang ada sudah sesuai dengan macam-macam garis namun penggunaan garis terbanyak dimulai dari garis lengkung, garis gabungan, garis zig-zag, garis lurus, garis gelombang, dan paling sedikit menggunakan garis putus-putus. Unsur ruang dan waktu peserta didik lebih dominan pada bentuk informal saja, tetapi masih terlihat keindahannya. Penggunaan warna dan gradasi masih banyak peserta didik yang belum berani memberikan warna mencolok dalam karyanya termasuk dalam pembuatan gradasi, sehingga hasil warna yang didapatkan hampir mirip satu sama lain. Walaupun memiliki warna yang hampir sama, namun dalam karya peserta didik memiliki bentuk dan ruang yang berbeda, sehingga memiliki nilai estetikanya masing-masing karena di lihat dari sudut pandang yang berbeda-beda pula.

2. Sebuah produk lukisan peserta didik memiliki tipe lukisan yang berbeda-beda, karena setiap peserta didik memiliki 
imajinasi estetikanya masing-masing. Tipe produk lukisan kelas IIIA SD Muhammadiyah Condongcatur adalah tipe transparansi dan tipe naturalistik. Dengan tema "pantai" peserta didik melukis dengan imajinasinya masingmasing sesuai dengan tipe lukisan tranparansi walau sudah diberikan contoh oleh gurunya, namun hasil karya yang diberikan masih terlihat realistik sesuai dengan tipe lukisan naturalistik.

\section{Saran}

a. Bagi peserta didik, diharapkan mampu mengembangkan kreativitas dalam membuat lukisan dan berani mengekspresikan diri dalam sebuah karya seni lukis dengan cara mencari referensi dari sumber belajar yang ada.

b. Bagi guru, diharapkan tetap mempertahankan media dan model pembelajaran, serta mengembangkan media pembelajaran lebih banyak lagi agar tercapai pembelajaran yang lebih menyenangkan bagi peserta didik.

c. Bagi sekolah, tetap mempertahankan pembelajaran dan ekstrakurikuler seni lukis di sekolah agar kreatifitas peserta didik lebih berkembang.

\section{DAFTAR RUJUKAN}

Islamuddin, H. (2012). Psikologi Pendidikan. Yogyakarta: Pustaka Pelajar bekerja sama dengan STAIN Jember Press.

Kartika, D. S. (2017). Seni Rupa Modern.
Bandung: Rekayasa Sains.

Moleong, L. j. (2016). Metodologi Penelitian Kualitatif. Bandung: PT Remaja Rosdakarya.

Pamadhi, H. (2012). Pendidikan Seni. Yogyakarta: UNY Press.

Hajar Pamadhi, Evan Sukardi, A. M. (2011). Seni Keterampilan Anak. Jakarta: Universitas Terbuka.

Rustandi, T. (2009). Pintas Melukis Dengan Cat Akrilik. Jakarta Selatan: PT. Wahyu Media.

Sumanto. (2011). Pendidikan Seni Rupa di Sekolah Dasar. Malang: Fakultas Ilmu Pendidikan Universitas Negeri Malang.

Nelwandi Nelson. (2016). Kreativitas dan Motivasi Dalam Pembelajaran Seni Lukis. Ilmu Pengetahuan Sosial, 1, 4258.

Putra, G. L. A. K., \& Yasa, G. P. P. A. (2020). Estetika Karakter Animasi Pada Media Komunikasi Sosial Dengan Kategori Audience Remaja. Jurnal Bahasa Rupa. https://doi.org/10.31598/bahasarupa.v4i1 .576

Siswantari, H., \& Setyaningrum, F. (2019). Estetika Persepsi Sebagai Konsep Pengembangan Tari Islami Di Perguruan Tinggi Islam. Lentera Pendidikan: Jurnal Ilmu Tarbiyah Dan Keguruan, 22(2), 243. https://doi.org/10.24252/lp.2019v22n2i6

Sunarto, S. (2017). Estetika Dalam Konteks Pendidikan Seni. Refleksi Edukatika: Jurnal Ilmiah Kependidikan. https://doi.org/10.24176/re.v7i2.1216 